\title{
Haematological effects of chronic benzene poisoning in 217 workers
}

\author{
MUZAFFER AKSOY, KORAY DINÇOL, TURHAN AKGÜN, SAKIR \\ ERDEM, and GÜNÇÁĞ DINÇOL \\ Section of Haematology, 2nd Internal Clinic of Istanbul Medical School, Capa, Istanbul, Turkey
}

\begin{abstract}
Aksoy, M., Dinçol, K., Akgün, T., Erdem, S., and Dinçol, G. (1971). Brit. J. industr. Med., 28, 296-302. Haematologicol effects of chronic benzene poisoning in 217 workers. A haematological study consisting of the determination of RBC, WBC, PCV, platelets, and differential counts was carried out, together with bone marrow puncture and haemoglobin analyses in appropriate cases, on a control population of 100 normal people and on 217 male labourers, $95 \%$ of whom worked with solvents containing benzene in small shops manufacturing shoes under unhygienic conditions. The concentration of benzene in the workplaces ranged between 30 and 210 p.p.m., and the period of exposure between 3 months and 17 years.

In 51 of the 217 workers $(23.50 \%)$ haematological abnormalities attributable to chronic benzene poisoning were detected. Thus, leucopenia was present in $9.70 \%$, thrombocytopenia in $1.84 \%$, leucopenia associated with thrombocytopenia in $4.6 \%$, pancytopenia in $2.76 \%$, acquired pseudo-Pelger-Huet anomaly in $0.46 \%$, lymphocytosis in $0.46 \%$, giant platelets in $0.46 \%$, eosinophilia in $2.30 \%$, basophilia in $0.46 \%$, and eosinophilia associated with basophilia in $0.46 \%$ (the maximum normal levels for eosinophils and basophils were $8 \%$ and $2 \%$ respectively).

Acquired pseudo-Pelger-Huet anomaly was detected in a worker with heterozygous betathalassaemia $\left(\mathrm{HbA}_{2} 4.1 \%\right.$ and $\left.\mathrm{HbF} 8.7 \%\right)$ in whom the only effect of benzene was on the leucocyte nuclei, all other haematological values being within normal limits. On the other hand, in $33.1 \%$ of the workers the haemoglobin was less than $12 \mathrm{~g} / 100 \mathrm{ml}$ and in $32.7 \%$ the PCV was less than $40 \%$ with the MCV ranging between 86 and $96 \mu \mathrm{m}^{3}$. In none of them did MCV exceed $100 \mu \mathrm{m}^{3}$. Thirty-one per cent. of these anaemic workers were treated with adequate doses of oral iron, which resulted, in all cases, in a complete disappearance of the anaemia. Therefore, it is difficult to attribute this anaemia to the effect of benzene alone.

Thus it is concluded that benzene exerts its harmful effect, primarily on the leucocytes, with eosinophilia and basophilia as inconstant findings, secondarily on the platelets causing thrombocytopenia, and finally on all three series giving rise to pancytopenia.
\end{abstract}

The deleterious effect of benzene on the haemopoietic system is well known. The harmful effect of this aromatic hydrocarbon is due to its widespread use as an excellent solvent. During the last few years numerous patients with aplastic anaemia and some with acute myeloblastic leukaemia due to chronic benzene poisoning have been detected among shoemakers in Istanbul (Aksoy, Dinçol, Akgün, Erdem, and Dinçol, 1970a). Hence an investigation was carried out on 217 apparently healthy workers manufacturing shoes under unhygienic conditions with solvents containing benzene. 


\section{Material}

Two hundred and seventeen apparently healthy male workers aged from 12 to 58 (mean 24.7) years were investigated, together with 100 male controls aged from 17 to 58 (mean 26.6) years who were randomly selected from among healthy and mostly young hospital personnel, medical students, and people accompanying patients to our outpatient department, whose living standards roughly resembled those of the workers who were investigated.

The working conditions of all workers were not good as their small shops were usually unhygienic and poorly ventilated. The concentration of benzene in the working environment, which ranged between 15 and 30 p.p.m. outside working hours, was found to reach a maximum of 210 p.p.m. when adhesives containing benzene were being used. The period of exposure to benzene ranged between 3 months and 17 years.

\section{Methods}

All haematological methods were standard. Haemoglobin determinations were carried out by the oxyhaemoglobin method using a standardized Klett-Summerson photoelectric colorimeter. PCV was determined in microhaematocrit tubes and platelet levels were assessed by an indirect counting method as modified by Aksoy, Dinçol, Dinçol, and Erdem (1970b), the results being checked in most instances by Brecher and Cronkite's direct method (1950). The morphology of platelets in the peripheral blood was also carefully studied in each case. In some cases spontaneous aggregation and adhesion as well as viscous metamorphosis were studied (Caen, Castaldi, Leclerc, Inceman, Larrieu, Probst, and Bernard, 1966; Balkuv and Ulutin, 1967). Smears of peripheral blood and bone marrow were stained by the MayGrünwald-Giemsa technique. Fetal haemoglobin determinations were performed by the method of Singer, Chernoff, and Singer (1951).

The concentrations of the benzene vapour in the working environment were measured by a Dräger Multigas Detector. ${ }^{1}$

\section{Results and comments}

The results of the investigations carried out in 217 apparently healthy workers using materials containing benzene are shown (Table 1). They illustrate the known deleterious effect of benzene on the haemopoietic system. After a period ranging between 3 months and 17 years of rather heavy exposure to benzene serious effects of chronic benzene poisoning such as leucopenia, thrombocytopenia, leucopenia associated with thrombocytopenia, and pancytopenia were observed in $18.90 \%$ of the workers studied. Apart from that, this incidence increased to $23.50 \%$ if other findings possibly attributable to chronic benzene poisoning are added, such as acquired pseudo-Pelger-Huet anomaly, lympho-

${ }^{2}$ Dräger Gasspürgerat/Multi-Gas Detector Mod. 21/23 Lübeck, Germany.
TABLE 1

Results ObTained from Haematological INVESTIGATION OF 217 APPARENTLY HeAlThy Workers USING Materials Containing BENZENE

\begin{tabular}{|c|c|c|}
\hline $\begin{array}{c}\text { Type of haematological } \\
\text { change }\end{array}$ & $\begin{array}{c}\text { No. of } \\
\text { workers with } \\
\text { haematological } \\
\text { changes }\end{array}$ & $\begin{array}{l}\text { Haematological } \\
\text { change } \\
(\%)\end{array}$ \\
\hline $\begin{array}{l}\text { Leucopenia }^{1} \\
\text { Thrombocytopenia } \\
\text { Teucopenia associated } \\
\text { with thrombocytopenia } \\
\text { Pancytopenia .. }\end{array}$ & $\begin{array}{r}21 \\
4 \\
10 \\
6\end{array}$ & $\begin{array}{l}9 \cdot 70 \\
1 \cdot 84 \\
\\
4 \cdot 60 \\
2 \cdot 76\end{array}$ \\
\hline $\begin{array}{c}\text { Leucocytosis } \ldots \\
\text { Leucocytosis associated } \\
\text { with thrombocytosis. . }\end{array}$ & $\begin{array}{l}5^{5} \\
2^{5}\end{array}$ & $\begin{array}{l}2 \cdot 30 \\
0.92\end{array}$ \\
\hline 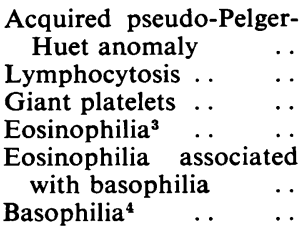 & $\begin{array}{l}1 \\
1 \\
1 \\
5 \\
1 \\
1 \\
1\end{array}$ & $\begin{array}{l}0.46 \\
0.46 \\
0.46 \\
2 \cdot 30\end{array}$ \\
\hline
\end{tabular}

${ }^{1}$ Leucopenia: WBC less than $4,000 / \mathrm{mm}^{2}$.

2Thrombocytopenia: platelets less than $144,000 / \mathrm{mm}^{3}$ by the method of Brecher and Cronkite (1950).

${ }^{3}$ Eosinophilia: eosinophils more than $8 \%$.

${ }^{4}$ Basophilia: basophils more than $2 \%$.

${ }^{5}$ See text.

cytosis, giant platelets, eosinophilia, and basophilia. On the other hand, the incidence of leucocytosis and leucocytosis associated with thrombocytosis observed in five and two workers respectively (Table 1) have not been added to the total incidence of haematological changes, as the authors are not sure that these findings are directly related to the well-established effects of chronic exposure to benzene.

The ages of the workers with haematological changes ranged between 12 and 58 years. Twentythree of the 51 workers, i.e., $45 \%$ of the subgroup with haematological changes, were between 13 and 20 years of age. On the other hand, $45 \%$ of the total number of workers investigated were also aged between 12 and 20 years. Thus, as the two percentages do not differ from one another, it was concluded that there probably was no correlation between the ages of the workers and the haematological changes observed.

Table 2 shows the relation of the period of exposure to the incidence of haematological changes in 51 of 217 workers. From this Table the incidence appears to be independent of the time of exposure (the small differences in the individual incidences are not statistically significant, $P$ approximately $0 \cdot 5$ ). 
TABLE 2

Relation of Period of ExPosure to INCIDENCE of Haematological Changes in 51 of 217 WORKERS

\begin{tabular}{|c|c|c|c|c|c|}
\hline \multirow[t]{2}{*}{$\begin{array}{c}\text { Duration of } \\
\text { exposure } \\
(y r)\end{array}$} & \multicolumn{2}{|c|}{$\begin{array}{c}\text { All exposed } \\
\text { workers }\end{array}$} & \multicolumn{2}{|c|}{$\begin{array}{l}\text { Workers with } \\
\text { haematological } \\
\text { changes }\end{array}$} & \multirow[t]{2}{*}{$\begin{array}{l}\text { Incidence } \\
\frac{B}{A} \times 100\end{array}$} \\
\hline & No. $(A)$ & $\%$ & No. (B) & & \\
\hline Less than 1 & 16 & $7 \cdot 37$ & 5 & $9 \cdot 81$ & 31 \\
\hline $1-$ & 109 & $50 \cdot 23$ & 24 & $47 \cdot 05$ & 22 \\
\hline $5-$ & 73 & $33 \cdot 64$ & 18 & $35 \cdot 29$ & 25 \\
\hline \multirow[t]{2}{*}{$10-17$} & 19 & $8 \cdot 76$ & 4 & $7 \cdot 85$ & 21 \\
\hline & 217 & $100 \cdot 00$ & 51 & $100 \cdot 00$ & \\
\hline
\end{tabular}

This could be interpreted as meaning that all haematological changes occur (or start) in the first year of exposure. Alternatively, if the proportion of workers from the affected group leaving the industry was higher than the proportion leaving from the total group, this could mask the appearance of cases occurring in later years of exposure.

Haematological changes observed in 217 workers exposed to benzene compared to 100 control subjects

Leucocytes As can be seen from Table 1, benzene exerts its effects mainly on leucocytes. According to our findings, the most frequently encountered haematological change in chronic benzene poisoning was in the white blood cell count which ranged between 2100 and $12800 / \mathrm{mm}^{3}$. Leucopenia alone was encountered in 21 workers $(9.70 \%)$, leucopenia associated with thrombocytopenia in $10(4.6 \%)$, and leucopenia as a part of pancytopenia in six $(2.76 \%)$. In other words, in 37 workers $(17.05 \%)$, the white cell count was less than $4000 / \mathrm{mm}^{3}$.

The mean white blood cell count for 212 workers, five of whom were excluded because of the presence of acute rheumatic fever or a transient leucocytosis or both, was $5468 / \mathrm{mm}^{3}$ (S.D. \pm 1 827). The mean white cell count for the control group was $6196 / \mathrm{mm}^{3}$ (S.D. \pm 1 302) $\mathrm{P}<0.001$.

Besides these quantitative changes in the number of leucocytes, the effect of benzene on the leucocytes can be exemplified by the occurrence of acquired pseudo-Pelger-Huet anomaly, lymphocytosis, eosinophilia, basophilia, and eosinophilia associated with basophilia. These changes were observed separately in nine workers. Thus the harmful effects of benzene on leucocytes were detected in a total of 46 workers $(21 \cdot 19 \%)$.

Acquired pseudo-Pelger-Huet anomaly This was observed in a 19-year-old beta-thalassaemic worker with seven years' exposure. His leucocyte count was $5800 / \mathrm{mm}^{3}$, the majority of which had only bilobed nuclei. Band forms comprised $22 \%$ of the total leucocytes. Apart from that no other haematological abnormality was detected in the peripheral blood of this patient. On the other hand, a frank maturation arrest was found on examination of the bone marrow. Fifteen days after the cessation of exposure there was a marked decrease in the percentage of band forms. Haemoglobin analysis of this patient revealed increased levels of haemoglobins $F$ and $A_{2}, 8.9$ and $4.1 \%$, respectively. These findings are consistent with the diagnosis of heterozygous betathalassaemia. In this beta-thalassaemic heterozygote, the pseudo-Pelger-Huet anomaly had no familial character, and one month after the cessation of exposure the proportion of granulocytes showing this anomaly decreased rapidly.

In 1960 Paterni and Russo in Italy reported a severe and fatal case of chronic benzene poisoning in which an acquired pseudo-Pelger-Huet anomaly was present together with pancytopenia and its related hazardous consequences. As stated above, there was no pancytopenia in our beta-thalassaemic heterozygote with this leucocyte anomaly. According to Saita and Moreo (1959) and Gaultier, de Traverse, Coquelet, Loygue, Housset, and Gervais (1966), the behaviour of the haemopoietic system, including the results of haemoglobin analyses, is no different in beta-thalassaemic heterozygotes with chronic benzene poisoning than those in detected persons suffering from the same disease without the haemoglobinopathy. Contrary to this, Aksoy and Erdem (1969) found a very high level of fetal haemoglobin in two beta-thalassaemic heterozygotes suffering from aplastic anaemia due to chronic benzene poisoning. The investigators have tried to explain the considerable variation in the concentration of $\mathrm{HbF}$ encountered in beta-thalassaemic heterozygotes with aplastic anaemia due to chronic benzene poisoning by the theory that different genes are responsible for beta-thalassaemia.

The observations mentioned above, namely, acquired pseudo-Pelger-Huet anomaly and a very high level of fetal haemoglobin in beta-thalassaemic heterozygotes associated with chronic benzene poisoning, lead us to suggest that some forms of beta-thalassaemia increase the deleterious effects of benzene on the haemopoietic system.

Lymphopenia and lymphocytosis Goldwater (1941) has drawn attention to the presence of a relative and absolute lymphopenia in chronic benzene poisoning. In that study an absolute lymphopenia was detected in 28 of 37 workers with leucopenia $(75 \%)$. In only one worker with leucopenia was a mild absolute lymphocytosis present. In another worker with normal haematological findings, a mild absolute and 
relative lymphocytosis was detected together with an eosinophilia of $8 \%$. Bernard (1942) reported a marked or moderate lymphocytosis in several individuals with chronic benzene poisoning. Therefore we are inclined to consider the mild lymphocytosis in two of our workers the result of chronic exposure to benzene.

Eosinophilia In six workers $(2 \cdot 76 \%)$ the proportion of eosinophil leucocytes in the peripheral blood was higher than $8 \%$, which was the upper limit of eosinophils in the 100 control subjects apart from one who had $10 \%$ eosinophils. In one worker, in whom no clue for the presence of a parasitic infestation including hydatid cysts was found, the eosinophilia was as high as $39 \%$. Three months after the cessation of exposure, eosinophilia had fallen to $13 \%$. In another worker leucocopenia was associated with $9 \%$ eosinophilia. The mean eosinophil value for 217 workers was $2.75 \%(S D \pm 0.9)$. On the other hand, the mean value and standard deviation for the control group were $2.7 \%( \pm 2.0)$; for the mean differences between the values of eosinophils of the normal control subjects and of the workers under investigation $P$ was less than 0.9 , indicating that there was no significant difference between the values of exposed workers and those of the controls.

Although the presence of eosinophilia due to chronic benzene exposure has been reported by various authors, others have not been able to verify their results. According to Heim de Balzac and Lafont (1910), eosinophilia may be present in individuals with chronic benzene exposure, though no other haematological changes can be observed. Duvoir and Dérobert (1942) have recorded eosinophilia exceeding $5 \%$ in $21.8 \%$ of the 555 individuals exposed to benzene. In that study the maximum value of the eosinophil count was $18 \cdot 1 \%$. Similarly, Savilahti (1956) has found eosinophil levels ranging between 6 and $15.5 \%$ in 18 of a series of 147 individuals exposed to benzene. On the other hand, Hamilton-Paterson and Browning (1944) and Goldwater (1941) have not encountered eosinophilia in their series. According to our results $2.75 \%$ eosinophilia is an inconstant finding of the early stage of chronic benzene poisoning.

Basophilia In two workers the basophil leucocyte count was $3 \%$. In one of them basophilia was associated with a mild eosinophilia of $9 \%$. In the latter the leucocyte count was $4000 / \mathrm{mm}^{3}$. In both cases, a decrease in the basophil leucocytes to $2 \%$ three weeks after the cessation of exposure was recorded. The upper limit of the basophil leucocyte count in normal controls was $2 \%$. The mean basophil count for 217 workers was $0 \cdot 23 \%$ (SD $\pm 1 \cdot 7$ ). For 100 controls it was $0.33 \%( \pm 1.4)$. For the mean differences between the values of the normal control subjects and those of the workers under investigation $P$ was less than $0 \cdot 2$, showing that the difference between the values of the exposed workers and those of the controls was not significant.

An increase in basophil leucocytes was recorded by Smith (1928), though it has not been verified by others (Goldwater, 1941 ; Savilahti, 1956; Browning, 1965). From our results we would suggest that a mild basophilia may rarely be found in the early stages of chronic benzene poisoning.

Platelets Thrombocytopenia was detected in 20 workers $(9 \cdot 2 \%)$. Thrombocytopenia alone was present in only four workers $(1.84 \%)$. The platelet levels in these individuals ranged between 100000 and $140000 / \mathrm{mm}^{3}$ with the direct counting method of Brecher and Cronkite (1950). The in-vitro platelet functions, such as spontaneous aggregation and adhesion to glass, viscous metamorphosis, and ADP and distilled water induced aggregation, were normal (Caen and his colleagues, 1966; Balkuv and Ulutin, 1967). The mean platelet count for 217 workers was $417 \times 10^{3} / \mathrm{mm}^{3}\left(\mathrm{SD} \pm 117.5 \times 10^{3}\right)$. The platelet count for the control group was $514 \times 10^{3} / \mathrm{mm}^{3}$ (SD $\left.84.5 \times 10^{3}\right)$. For the mean differences between the values of the normal control subjects and those of the workers under investigation $P$ was less than 0.001 .

Apart from that, giant platelets were observed in the peripheral blood of one worker in whom the platelet counts were within normal limits. In this patient, after cessation of exposure, the giant platelets gradually disappeared. In 10 workers $(4.6 \%)$ an association of thrombocytopenia and leucopenia was detected. The white blood cell counts of these subjects ranged between 2200 and $3200 / \mathrm{mm}^{3}$. The range for platelets was between 100000 and $143000 / \mathrm{mm}^{3}$.

A decrease in the platelet count, in varying degrees, has been reported in cases of chronic benzene poisoning. According to Savilahti (1956), thrombocytopenia is the most frequent and sometimes the only finding in chronic benzene poisoning. Goldwater (1941), on the other hand, regards thrombocytopenia as being less frequent than anaemia and macrocytosis. Grazioli and Monteverde (1960) reported that thrombocytopenia was not a constant finding in the majority of cases resulting from chronic benzene exposure.

Leucocytosis and leucocytosis associated with thrombocytosis Leucocytosis alone and in association with thrombocytosis was observed in five and two workers, respectively. In one patient each of the former and the latter groups these haematological changes were due to an acute attack of rheumatic fever. Similarly, in two subjects of the former and in one of the latter groups no obvious cause for these 
haematological changes could be identified. Also, in two patients with leucocytosis, the finding was transient and disappeared within a few days.

Although the possibility cannot be completely ruled out, it is difficult to attribute leucocytosis and leucocytosis associated with thrombocytosis solely to chronic benzene exposure. Nevertheless the situation may be similar to the effect of some myelotoxic agents, such as nitrogen mustard and cyclophosphamide, which sometimes cause a temporary increase in leucocytes at the beginning of treatment.

Pancytopenia Pancytopenia was detected in six of the 217 workers $(2 \cdot 76 \%)$. The interesting point was that pancytopenia had not progressed sufficiently to give rise to signs and symptoms of aplastic anaemia. It was after the detection of aplastic anaemia that the specific treatment was started. In these cases the red blood cells ranged between 2100000 and $3700000 / \mathrm{mm}^{3}$, PCV between 18 and $36 \%$, white blood cells between 2100 and $3800 / \mathrm{mm}^{3}$, haemo- globin between 6.3 and $10.7 \mathrm{~g} / 100 \mathrm{ml}$, and platelets between 65000 and $152000 / \mathrm{mm}^{3}$. In four of these cases fetal haemoglobin ranged from $3 \cdot 1$ to $16.8 \%$. In only one worker was the haemoglobin F $1.8 \%$.

Haemoglobin and PCV Haemoglobin levels were less than $12 \mathrm{~g} / 100 \mathrm{ml}$ in 72 of the workers $(33.1 \%)$ and in $71(32.7 \%)$ the PCV was less than $40 \%$. In these workers, associated with low levels of haemoglobin and PCV, the mean corpuscular volume ranged between 86 and $96 \mu \mathrm{m}^{3}$ and never exceeded $100 \mu \mathrm{m}^{3}$. On the other hand, in these workers the mean corpuscular haemoglobin concentration never exceeded $30 \%$. According to these values, the anaemia, mild or moderate in degree, was not macrocytic and hyperchromic. On the other hand, 23 workers (31\% of anaemic individuals) have responded to treatment with oral iron of approximately one and a half months' duration, at the end of which normal haemoglobin and PCV values have been obtained. In 17 of 100 controls the haemoglobin

TABLE 3

Results of Bone Marrow Punctures Performed in 11 Apparently Healthy Workers Using Materials Containing Benzene

\begin{tabular}{|c|c|c|c|c|c|}
\hline \multirow{2}{*}{ Case } & \multirow{2}{*}{$\begin{array}{c}\text { Type of haematological } \\
\text { changes }\end{array}$} & \multicolumn{4}{|c|}{ Bone marrow findings } \\
\hline & & Cellularity & Myeloid series & Erythroid series & $\begin{array}{c}\text { Mega- } \\
\text { karyocytes }\end{array}$ \\
\hline 1 & Leucopenia + thrombo- & Normocellular & No change & No change & Present \\
\hline & cytopenia & Normocellular & Maturation arrest & Vacuolization & $\begin{array}{l}\text { Decreased in } \\
\text { number }\end{array}$ \\
\hline 3 & $\begin{array}{l}\text { Leucopenia + thrombo- } \\
\text { cytopenia } \\
\text { Leucopenia + thrombo- }\end{array}$ & Slightly hypocellular & No change & No change & Present \\
\hline 5 & $\begin{array}{l}\text { cytopenia } \\
\text { Acquired pseudo-Pelger- }\end{array}$ & Slightly hypocellular & Maturation arrest & No change & Present \\
\hline & Huet-anomaly & Hypercellular & $\begin{array}{l}\text { Marked maturation } \\
\text { arrest }\end{array}$ & $\begin{array}{l}\text { Slight maturation } \\
\text { arrest }\end{array}$ & Present \\
\hline 6 & Lymphocytosis & Normocellular & $\begin{array}{l}\text { Vacuolization in myelo- } \\
\text { cytes }\end{array}$ & No change & Present \\
\hline 7 & Pancytopenia & Normocellular & Maturation arrest & Maturation arrest & Present \\
\hline $\begin{array}{l}8 \\
9\end{array}$ & $\begin{array}{l}\text { Pancytopenia } \\
\text { Pancytopenia }\end{array}$ & Normocellular & No change & No change & Present \\
\hline & Pancytopenia & Normocellular & $\begin{array}{l}\text { Maturation arrest, } \\
\text { vacuolization in my- } \\
\text { elocytes and plasma } \\
\text { cells arrest }\end{array}$ & No change & Present \\
\hline 10 & Pancytopenia & Slightly hypocellular & $\begin{array}{l}\text { Maturation arrest, } \\
\text { vacuolization in my- } \\
\text { elocytes and plasma } \\
\text { cells arrest }\end{array}$ & No change & Present \\
\hline 11 & Pancytopenia & $\begin{array}{l}\text { Slightly hypocellular with } \\
\text { mild increase in } \\
\text { lymphocytes }\end{array}$ & No change & No change & Present \\
\hline
\end{tabular}


levels were less than $12 \mathrm{~g} / 100 \mathrm{ml}$, and in 21 the PCV was less than $40 \%$.

Anaemia, according to Goldwater (1941), is the most frequent finding in chronic benzene poisoning, the decrease in haemoglobin being less than that of the red blood cells. Similarly, Savilahti (1956) has reported the presence of a mild anaemia as a constant finding which was usually hypochromic in type. Browning (1965), on the other hand, has stated that in the early stage of mild chronic benzene poisoning, anaemia may be transient but may gradually increase in severity in proportion to the extent of exposure. Furthermore, Kühböck and Lachnit (1962) did not confirm macrocytosis as an infallible sign of early benzene poisoning.

We found a mild or moderate hypochromic or normochromic anaemia in almost $33 \%$ of the 217 workers investigated. The same finding was present in only $21 \%$ of the control group. Thus treatment with oral iron was given to some $(31 \%)$ of the anaemic workers with a resulting disappearance of the anaemia. Therefore, the presence of an irondeficiency anaemia in association with the finding of chronic benzene poisoning was a possibility, though the effects of chronic exposure to benzene cannot be ruled out completely.

Bone marrow The state of the bone marrow was investigated in 11 workers, four with leucopenia associated with thrombocytopenia, one with lymphocytosis, one with acquired pseudo-Pelger-Huet anomaly, and five with pancytopenia (Table 3). No remarkable changes were observed in two of them. In only one of the remainder was the bone marrow hypercellular with a maturation arrest in the erythroid and myeloid series. In another case, the bone marrow was slightly hypercellular with the arrest of maturation in the granulocytic series. In two workers the bone marrow was normocellular, and in three slightly hypocellular, with maturation arrest in both the erythroid and myeloid series. In another three, the bone marrow showed marked vacuolization.

A great variation in the bone marrow findings has been reported both in animals poisoned with benzene experimentally and in human beings with the signs and symptoms of chronic benzene intoxication (Mallory, Gall, and Brickley, 1939; Browning, 1965; Wintrobe, 1967). The same variation was detected to a lesser extent in the 11 workers in our series in whom features accompanying the early stages of chronic benzene poisoning were present. In the majority of our cases the bone marrow smears were normocellular; in the others they were either hypocellular or hypercellular. Some of them also had a maturation arrest in either the erythroid or myeloid series or in both. In some, the only abnormal finding was the vacuolization detected in the myelocytes or plasma cells (case 9). Furthermore, in two subjects there was no change in the bone marrow smears in spite of the leucopenia associated with thrombocytopenia or pancytopenia (cases 1 and 8 ).

This investigation was supported by a grant (TAG/99) from the Scientific and Technical Council of Turkey.

\section{References}

Aksoy, M., Dinçol, K., Akgün, T., Erdem, S., and Dinçol, G. (1970a). Clinical and laboratory observations in 32 patients with aplastic anaemia and 2 with acute myeloblastic leukemia due to chronic benzene poisoning. Abstract Volume XIII. Int. Congr. Haemat., Munich, 2-8 August, 1970, p. 134.

—, Dinçol, G., Dinçol, K., and Erdem, S. (1970b). A simple indirect method for the enumeration of blood platelets. To be published.

_ and Erdem, S. (1969). Some problems of hemoglobin patterns in different thalassemic syndromes showing the heterogeneity of beta-thalassemia genes. Ann. N.Y. Acad. Sci., 165, 13-24.

Balkuv, S., and Ulutin, O. N. (1967). Trombosit agregasyon defektlerini meydana çikarmak için yeni basit bir metod. Istanbul. Univ. Tip Fak. Mec., 30, 431-436.

Bernard, J. (1942). La lymphocytose benzénique. Sang, 15, 501.

Brecher, G., and Cronkite, E. P. (1950). Morphology and enumeration of human blood platelets. J. appl. Physiol., 3, 365-377.

Browning, E. (1965). Toxicity and Metabolism of Industrial Solvents, p. 3. Elsevier, Amsterdam.

Caen, J. P., Castaldi, P. A., Leclerc, J. C., Inceman, S., Larrieu, M. J., Probst, M., and Bernard, J. (1966). Congenital bleeding disorders with long bleeding time and normal platelet count. I. Glanzmann's thrombasthenia. (Report of fifteen patients.) Amer. J. Med., 41, 4-26.

Duvoir, M., and Dérobert, L. (1942). L'éosinophilie des benzéniques. Sang, 15, 241-248.

Gaultier, M., de Traverse, P. M., Coquelet, M. L., Loygue, A. M., Housset, H., and Gervais, P. (1966). Hémoglobinopathies observées en milieu professionnel. Bull. Inst. nat. Santé Recherche méd., 21, 1047-1062.

Goldwater, L. J. (1941). Disturbances in the blood following exposure to benzol. J. Lab. clin. Med., 26, 957-973.

Grazioli, G., and Monteverde, C. A. (1960). Cited by L. Resegotti in Survey of the Italian literature on industrial medicine. Panminerva med., 2, 142-143.

Hamilton-Paterson, J. L., and Browning, E. (1944). Toxic effects in women exposed to industrial rubber solutions. Brit. med. J., 1, 349-352.

Heim de Balzac, F., and Lafont, E. A. (1910). (Cited by E. Browning.) Réactions hématiques du benzénisme professionel. Ass. franç. pour l'advancement des Sciences, Congrès de Toulouse.

Kühböck, J., and Lachnit, V. (1962). Zum Problem der Früherfassung von Benzol- und Toluolschäden. Int. Arch. Gerwerbepath Gewerbehyg., 19, 149-157.

Mallory, T. B., Gall, E. A., and Brickley, W. J. (1939). Chronic exposure to benzene (benzol.). III. The pathologic results. $J$. industr. Hyg., 21, 355-393.

Paterni, L., and Russo, G. (1960). Il primo case di anomalia Pelgheriana nella emopatia benzenica; associazone con nanismo cellulare. Haematologica, 45, 213-220.

Saita, G., and Moreo, L. (1959). Talassemia ed emopatie professionali. Nota 1-Talassemia e benzolismo cronico. Med. d. Lavoro, 50, 25-44. 
Savilahti, M. (1956). Mehr als 100 Vergiftungsfälle durch Benzol in einer Schuhfabrik. Arch. Gewerbepath. Gewerbehyg., 15, 147-157.

Singer, K., Chernoff, A. I., and Singer, L. (1951). Studies on abnormal hemoglobins. I. Their demonstration in sickle cell anemia and other hematologic disorders by means of alkali denaturation. Blood, 6, 413-428.

Smith, A. R. (1928). Chronic benzol poisoning among women industrial workers. J. industr. Hyg., 10, 73-93.

Wintrobe, M. M. (1967). Clinical Hematology, 5th ed., p. 789. Lea and Febiger, Philadelphia.

Received for publication June 5, 1970. 